\title{
Introduction: law and economics of federalism
}

\section{Jonathan Klick}

The economic theory of federalism has been well discussed through the years. Wallace Oates (1972) largely started the systematic study of economic federalism, from both normative and positive perspectives, and the subsequent fiscal federalism literature is well developed. ${ }^{1}$ The basic theoretical framework involves the recognition that there is preference heterogeneity across jurisdictions (which can affect the optimal level of public good provision) pushing in favor of smaller decision-making units, balanced by the possibility that cross-jurisdictional externalities exist as well as the potential gains from scale economies in production. The optimal system, then, is one that sets the marginal loss from increasing the jurisdictional level at which decisions regarding a public good are made equal to the gain achieved by internalizing jurisdictional externalities and exploiting economies of scale. The so-called decentralization or subsidiarity principle embodies this trade-off.

Subsequent economic discussions of federalism have included their political economy aspects (see, for example, Inman and Rubinfeld 1997 and Weingast 2009), including analyses from a constitutional economics perspective (Mueller 1996; Buchanan 2001). Legal scholars have used the economic model of federalism, but have also critiqued it for failing to recognize important practical limitations, such as a failure to distinguish between regulatory and fiscal federalism (see, for example, Super 2005). Beyond these criticisms, legal scholars have distinguished among cooperative and competitive federalism, as well as "uncooperative federalism" (Bulman-Pozen and Gerken 2009). All of these models and perspectives help to elucidate the ways that various levels of government interact, making the normative prescriptions somewhat more complicated than the decentralization principle would otherwise suggest.

While the literatures, in economics and law, on federalism are vibrant,

1 For overviews, see Oates $(1999,2005)$ and Inman and Rubinfeld (forthcoming). 
insightful, and challenging, they have been well covered in collections like this previously. ${ }^{2}$ Instead, in this collection, the focus is on using federalism as a vehicle for the empirical identification of policy effects. In some sense, this collection takes one of the oldest theoretical takes on federalism in the law and puts it in the service of the new empirically minded law and economics. In 1932, in the case New State Ice Co. v. Liebmann, Justice Louis Brandeis famously stated "[a] state may, if its citizens choose, serve as a laboratory; and try novel social and economic experiments without risk to the rest of the country." 3

It is through state experimentation that we have learned much of what we know regarding the effects of many policies. A federalist structure, at least in principle, allows for quasi-experimental examinations and evaluations of the effects of various policies that would be more difficult in unitary systems. Because the lower level jurisdictions share much in common with each other (since all are affected by identical federal laws) they potentially serve as decent counterfactual comparisons for each other when one engages in a policy experiment. Further, the existence of instances where the federal government steps in (e.g., through the passage of a binding national law or the preemption of the law of the lower jurisdiction) plausibly creates additional policy variation that may be conditionally random, allowing for the credible identification of causal effects.

Such an approach has been used to examine laws in the US states for at least two decades. In the chapters that follow, there is a generalized discussion of much of this work in the environmental context (Fleck and Hanssen) and social welfare programs (Gelbach; Bitler and Zavodny). Additionally, largely new empirical work is provided on the effect of state regulations on entrepreneurism (Sobel and Dove), consumer protection law (Wright), and crime policies (Owens). This volume also provides an analysis of inter-jurisdictional arrangements on the development of Native American communities (Anderson and Parker), as well as the interplay among the levels of government when it comes to budgetary issues (Galle). Lastly, because this kind of empirical work is under-developed in the European Union, this volume provides institutional background for the way the effectively federalist system works in Europe with some discussion of issues that hopefully spur comparable empirical work in that context.

2 See, for example, Kobayashi and Ribstein (2007), Ahmad and Brosio (2006), Oates (1998), etc.

3 New State Ice Co. v. Liebmann, 285 U.S. 262 (1932). 


\section{REFERENCES}

Ahmad, Ehtisham, and Giorgio Brosio (2006), Handbook of Fiscal Federalism, Edward Elgar Publishing.

Buchanan, James M. (2001), The Collected Works of James M. Buchanan, Volume 18: Federalism, Liberty, and the Law, Liberty Fund, Inc.

Bulman-Pozen, Jessica, and Heather K. Gerken (2009), "Uncooperative Federalism," Yale Law Journal, 118(7): 1256-310.

Inman, Robert P., and Daniel L. Rubinfeld (1997), "The Political Economy of Federalism," in Perspectives on Public Choice: A Handbook, D.C. Mueller, ed., Cambridge University Press.

Inman, Robert P., and Daniel L. Rubinfeld (forthcoming), "Economics of Federalism," in Oxford Handbook of Law and Economics, F. Parisi, ed., Oxford University Press.

Kobayashi, Bruce H., and Larry E. Ribstein (2007), Economics of Federalism, Edward Elgar Publishing.

Mueller, Dennis C. (1996), Constitutional Democracy, Oxford University Press.

Oates, Wallace E. (1972), Fiscal Federalism, London, Harcourt Brace Jovanovich.

Oates, Wallace E. (1998), The Economics of Fiscal Federalism and Local Finance, Edward Elgar Publishing.

Oates, Wallace E. (1999), “An Essay on Fiscal Federalism,” Journal of Economic Literature, 37(3): 1120-49.

Oates, Wallace E. (2005), "Toward A Second-Generation Theory of Fiscal Federalism," International Tax and Public Finance, 12(4): 349-73.

Super, David A. (2005), "Rethinking Fiscal Federalism," Harvard Law Review, 118(8): 2544-652.

Weingast, Barry R. (2009), "Second Generation Fiscal Federalism: The Implications of Fiscal Incentives," Journal of Urban Economics, 65(3): 279-93. 
Jonathan Klick - 9781786433602 Downloaded from PubFactory at 04/26/2023 07:49:38AM via free access 